Article

\title{
Effect of Cooling Rate on Microstructure and Mechanical Properties in the CGHAZ of Electroslag Welded Pearlitic Rail Steel
}

\author{
Adnan Raza Khan, Shengfu Yu *, Hao Wang and Yuan Jiang \\ State Key Laboratory of Materials Processing and Die \& Mould Technology, Huazhong University of Science and \\ Technology, Wuhan 430074, China \\ * Correspondence: yushengfu@hust.edu.cn; Tel.: +86-27-8755960
}

Received: 5 June 2019; Accepted: 28 June 2019; Published: 30 June 2019

\begin{abstract}
The effect of cooling rate, ranging from 6 to $1{ }^{\circ} \mathrm{C} / \mathrm{s}$, on microstructure and mechanical properties in the coarse-grained heat affected zone (CGHAZ) of electroslag welded pearlitic rail steel has been investigated by using confocal scanning laser microcopy (CSLM) and Gleeble 3500 thermo-mechanical simulator. During heating, the formed austenite was inhomogeneous with fractions of untransformed ferrite, which has influenced the pearlite transformation during cooling by providing additional nucleation sites to pearlite. During cooling, at $6{ }^{\circ} \mathrm{C} / \mathrm{s}$, the microstructure was composed of martensite and bainite with little pearlite. From 4 to $1{ }^{\circ} \mathrm{C} / \mathrm{s}$, microstructures were completely pearlite. Lowering the cooling rate of the CGHAZ from 4 to $1{ }^{\circ} \mathrm{C} / \mathrm{s}$ increased the pearlite start temperature and reduced the pearlite growth rate. Meanwhile, this increase in pearlite start temperature enlarged the pearlite interlamellar spacing. Alternatively, increasing pearlite interlamellar spacing in the CGHAZ by lowering the cooling rate from 6 to $1{ }^{\circ} \mathrm{C} / \mathrm{s}$ reduced the hardness and tensile strength, whereas toughness was found unaffected by the pearlite interlamellar spacing. It has been found that a cooling rate of $4{ }^{\circ} \mathrm{C} / \mathrm{s}$ leads to the formation of pearlite with fine interlamellar spacing of $117 \mathrm{~nm}$ in the CGHAZ of electroslag welded pearlitic rail steel where hardness is $425 \mathrm{HV}$, tensile strength is $1077 \mathrm{MPa}$, and toughness is $9.1 \mathrm{~J}$.
\end{abstract}

Keywords: pearlitic rail steel; electroslag welding; coarse-grained heat affected zone (CGHAZ); microstructure; mechanical properties

\section{Introduction}

Continuous welded pearlitic rails (CWR) are widely used in railroad applications where thermite welding and flash butt welding are the joining techniques [1-5]. Large axel load and fast speed train are the major thrust areas which have made the coarse-grained heat affected zone (CGHAZ) the most critical zone, as failure has been observed in many studies [5-10]. To overcome this, electroslag welding is an alternative welding process where by changing the welding parameters a wide range of cooling rates can be achieved, leading to a variety of microstructures and mechanical properties. Porcaro et. al. mention that in the welding of pearlitic rail steel, by varying the welding parameters, cooling rates can be achieved in the range of 10 to $1{ }^{\circ} \mathrm{C} / \mathrm{s}$ [1]. Micenko and Li infer that in the welding of pearlitic rail steel an ideal microstructure in the CGHAZ would be pearlite with fine interlamellar spacing, which should be the consequence of a specific cooling rate [9]. This requires a fundamental and comprehensive understanding of microstructure formation and pearlite interlamellar spacing that occur in the CGHAZ under different cooling rates.

Grigorenko et al. performed a series of experiments on the CGHAZ of flash butt welded M76 pearlitic rail steel under different cooling rates ranging from $30^{\circ} \mathrm{C} / \mathrm{s}$ to $5{ }^{\circ} \mathrm{C} / \mathrm{s}$, and mentioned that 
below $12{ }^{\circ} \mathrm{C} / \mathrm{s}$ pearlite starts to form [10]. Poznyakov et al. studied the microstructure transformation in $\mathrm{HAZ}$ of electric arc welded rail steel under different cooling rates ranging from $22^{\circ} \mathrm{C} / \mathrm{s}$ to $5{ }^{\circ} \mathrm{C} / \mathrm{s}$, and mentioned that at all cooling rates martensite formation and cracks have been observed [11]. Nevertheless, these given results pose fundamental problem in the CGHAZ which is not acceptable in field application, therefore it requires comprehensive investigation of the microstructure formation and associated mechanical properties in the CGHAZ of electroslag welded pearlitic rail steel. Wu et. al. reported that pearlite is a diverse microstructure where lowering the cooling rate can produce fine pearlite, as a $0.1^{\circ} \mathrm{C} / \mathrm{s}$ cooling rate in hypo-eutectoid steel can provide very fine pearlite interlamellar spacing of $40 \mathrm{~nm}$ [12]. However, Sahay et al. stated that, under continuous cooling, pearlite microstructure with fine interlamellar spacing can be achieved by rapidly cooling the sample to lower pearlite start temperature that is located just above the bainite start temperature in the continuous cooling transformation (CCT) diagram [13]. Modi et al. studied that in pearlite microstructure, pearlite interlamellar spacing governs the mechanical properties, especially the toughness, which can only be improved by decreasing the pearlite interlamellar spacing [14]. It is concluded that during pearlite formation in the CGHAZ, cooling rate and consequently pearlite interlamellar spacing are of great significance and guarantee the structural integrity and optimum combination of mechanical properties.

It has been noticed that heating stage in the CGHAZ during the welding of pearlitic rail steel is an important factor which essentially influences the microstructure formation while cooling $[15,16]$. Palmer et al. claimed that while welding ferritic-pearlitic steel, austenite first nucleates at the pearlite-pearlite interface and at the ferrite-pearlite interface; afterwards, austenite rapidly grows into the pearlite colonies. At this point pearlite transforms into high carbon concentration austenite, but the ferrite which was initially present at the austenite grain boundaries remains untransformed [17]. Consequently, the formed austenite in the CGHAZ will be inhomogeneous with fractions of untransformed ferrite. Elmer et al. mentioned that during the welding of pearlitic rail steel, inhomogeneous austenite with fractions of untransformed ferrite in the CGHAZ possibly influence the microstructure formation sequence during cooling [18]. Therefore, while investigating microstructure formation in the CGHAZ during cooling, the degree of austenite homogeneity must be accounted for.

Based on the above studies, it becomes crucial to investigate the microstructure and pearlite interlamellar spacing and their influence on the mechanical properties in the CGHAZ of electroslag welded pearlitic rail steel. To accomplish this, the in-situ microstructure formation and mechanical properties in the CGHAZ of pearlitic rail steel under different cooling rates ranging from 6 to $1{ }^{\circ} \mathrm{C} / \mathrm{s}$ have been investigated.

\section{Experimental Procedure}

U71Mn pearlite rail steel $(0.76 \% \mathrm{C}, 0.29 \% \mathrm{Si}, 1.23 \% \mathrm{Mn}, 0.019 \% \mathrm{~S}$ and $0.026 \% \mathrm{P})$ has been used for thermal simulation through high temperature confocal scanning laser microscopy (CSLM, Yonekura, Kanagawa, Japan) and Gleeble 3500 thermo-mechanical simulator (Gleeble, Shanghai, China). Microstructure transformation was analyzed by CSLM samples and mechanical properties were measured by Gleeble 3500 samples. Samples of $7 \mathrm{~mm}$ diameter and $3 \mathrm{~mm}$ height were used for CSLM; whereas dimensions of the samples used for Gleeble 3500 were $70 \mathrm{~mm} \times 11 \mathrm{~mm} \times 11 \mathrm{~mm}$. Ten samples for CSLM and twenty samples for Gleeble thermal simulation were prepared which were thermally simulated at five different cooling rates of $6,4,3,2$, and $1{ }^{\circ} \mathrm{C} / \mathrm{s}$, successively. The proposed thermal cycles were chosen based on experimentally measured thermal cycle in the CGHAZ during electroslag welding of pearlitic rail steel.

Thermal cycles were measured during electroslag welding at the head of rail steel by using K-type (nickel chromium-nickel silicon) thermocouple in the lab-view software (2014 version, HUST, Wuhan, China). Thermocouples were drilled into the rail head $10 \mathrm{~mm}$ below the rail running surface. Cooling rates, during welding, were varied by changing the welding parameters and the controlling the water flow rate into the copper mold. Figure 1a shows the experimentally measured thermal cycles in the CGHAZ of electroslag welded pearlitic rail steel, whereas proposed thermal cycles achieved during 
thermal simulation in CSLM are shown in Figure 1b. In simulation, heating rate was controlled by electrical resistance and cooling rate was controlled by He-gas spray. For all samples, the heating sequence from room temperature to $300^{\circ} \mathrm{C}$ at $1.5^{\circ} \mathrm{C} / \mathrm{s}$, from 300 to $1250^{\circ} \mathrm{C}$ at $10^{\circ} \mathrm{C} / \mathrm{s}$, and from 1250 to $1300{ }^{\circ} \mathrm{C}$ at $1.9^{\circ} \mathrm{C} / \mathrm{s}$, then cooling from 1300 to $800^{\circ} \mathrm{C}$ at $12.5^{\circ} \mathrm{C} / \mathrm{s}$ was the same. Afterwards, samples were cooled down to $100^{\circ} \mathrm{C}$ at different cooling rates of $6,4,3,2$, and $1{ }^{\circ} \mathrm{C} / \mathrm{s}$, successively. In-situ microstructure transformation was observed by CSLM. Optical microscope (OM, Eastcolight (HK) Ltd., Hongkong, China) and field emission scanning electron microscope (FESEM, Thermo-fisher, Waltham, MA, USA) were used to observe morphology of the various microstructures. To prepare samples for CSLM, OM, and FESEM the same steps were performed as per ASTM E003-01 [19]. Samples were polished in the usual way and finished on $0.25 \mu \mathrm{m}$ diamond paste. Finally, polishing by using colloidal silica was performed to retain the microstructural features. Nital (3\%) was used to reveal the microstructure. Field emission transmission electron microscope (FETEM, Thermo-fisher, Waltham, MA, USA), operated at $200 \mathrm{KV}$, was used for the measurement of pearlite interlamellar spacing. Interlamellar spacing was measured using TEM micrographs, with 10 fields studied for each case. The statistical uncertainties are referred to $+1 \sigma$. True interlamellar spacing was measured from the mean value $\left(\overline{S_{R}}\right)$ of measurements on random sections according to $S=0.5 \overline{S_{R}}[20,21]$. To prepare samples for TEM observation, foils of steel were thinned to less than $50 \mu \mathrm{m}$ with silicon carbide emery paper of 1200 grit size. Twin-jet electro polishing was then used to make it final by using a solution of $6 \%$ perchloric acid in methanol.
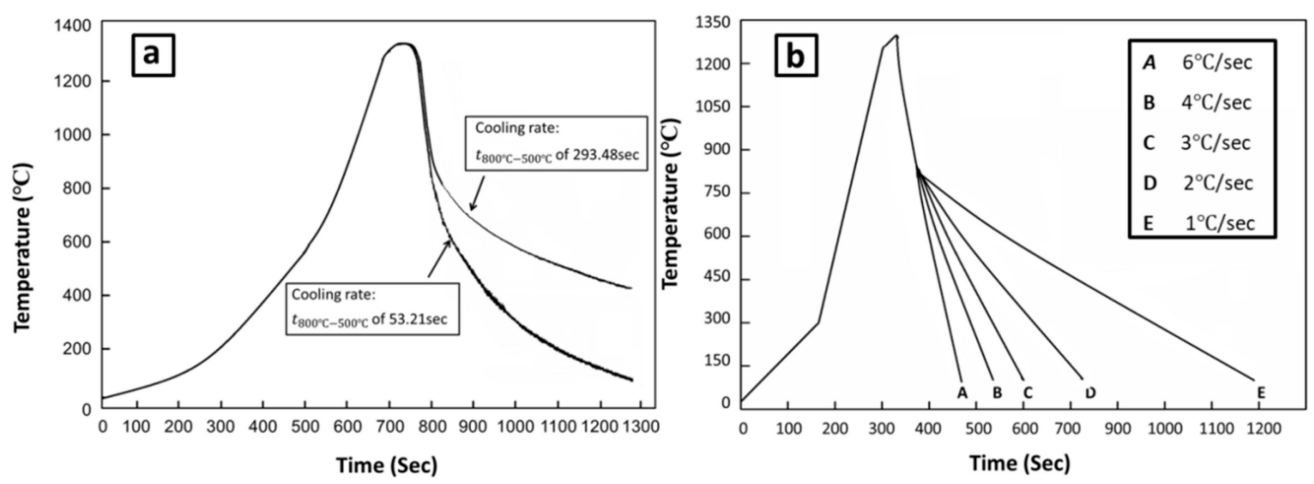

Figure 1. Thermal cycles in the coarse-grained heat affected zone (CGHAZ) of electroslag welded pearlitic rail steel. (a) Measured thermal cycles. (b) Thermal cycles achieved during confocal scanning laser microcopy (CSLM) and Gleeble simulation.

Gleeble 3500 samples were used for measuring mechanical properties. The micro hardness of all samples was measured by using Vickers hardness tester (load of $490 \mathrm{~g}$ for $15 \mathrm{~s}$ ). Six measurements of each sample were taken according to standard E092-17 [22]. Tensile strength, at room temperature, was measured according to ASTM standard A370-0a at strain rate of $0.005 S^{-1}$ [23], using AG-IC $100 \mathrm{KN}$ electronic universal tensile testing machine (SHIMADZU, Kyoto, Japan). Figure 2 shows the schematics of a sample used for tensile testing measurements. Charpy V-notch impact testing, at room temperature, was performed according to the ASTM standard E23-02a [24]. Three measurements were taken at each cooling rate for tensile strength and toughness measurement.

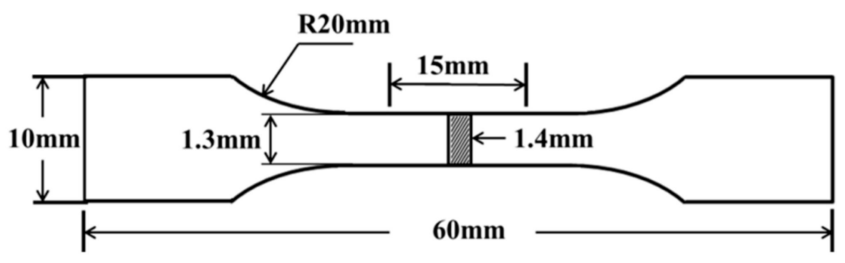

Figure 2. Schematic of tensile testing specimen. 


\section{Results and Discussions}

\subsection{Austenite Formation}

Figure 3 shows the behavior of austenite formation and grain growth during heating stage at heating rate of $10^{\circ} \mathrm{C} / \mathrm{s}$. Short-range carbon diffusion and limiting duration, due to high heating rate, shifted the nucleation of austenite towards high temperature of $810^{\circ} \mathrm{C}$, as shown in Figure $3 a$. The austenitization process was started at the pearlite, as shown in Figure $3 b$, where the nucleation sites of austenite were inside the pearlite colonies and at the pearlite-pearlite interface, as shown in Figure 4a. Afterwards, austenite growth happened by transforming the pearlite colonies, as shown in Figure 4b. Complete pearlite transformation into austenite was continued for 19-20 s and ended at $1005^{\circ} \mathrm{C}$, as shown in Figure 3c. Austenite grains formation was started at $1229^{\circ} \mathrm{C}$, as shown in Figure $3 \mathrm{~d}$. This austenite grain growth was sustained until the peak temperature of $1302{ }^{\circ} \mathrm{C}$, as shown in Figure 3e,f, successively. It has been observed that, even at the peak temperature of $1302{ }^{\circ} \mathrm{C}$ there are some traces of parent austenite grain boundaries, as shown in Figure $3 \mathrm{f}$, which are due to the presence of untransformed ferrite. Jacot et al. [25] and Atkinson et al. [26] have proposed a model of austenitization of pearlite, according to which the presence of untransformed ferrite even at the peak temperature of $1302{ }^{\circ} \mathrm{C}$ is due to the short-range carbon diffusion and limited duration during heating stage in the CGHAZ. It has been concluded that short-range carbon diffusion and limited duration due to high heating rate in the CGHAZ of pearlitic rail steel have made the austenite inhomogeneous, with fractions of untransformed ferrite.

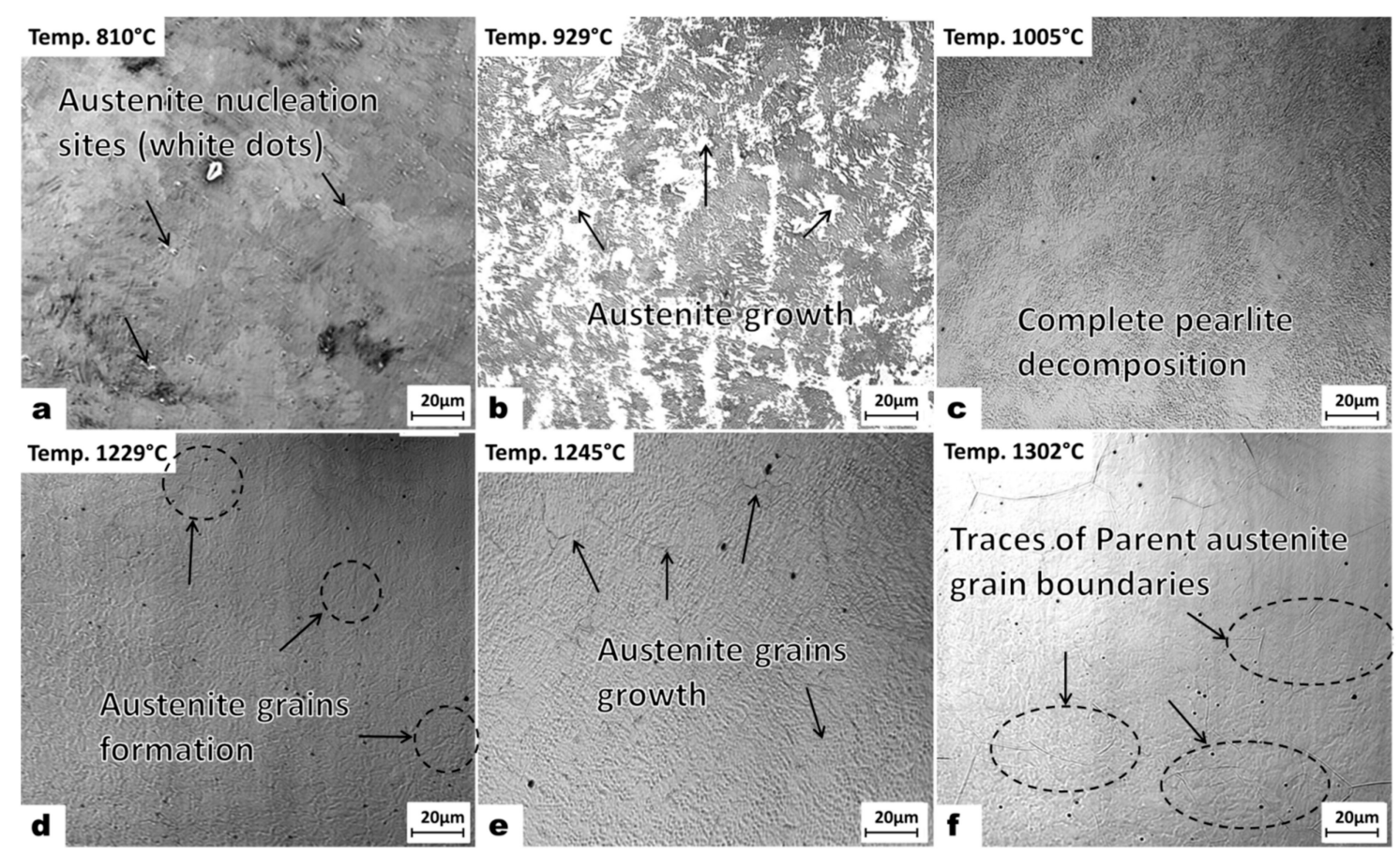

Figure 3. CSLM micrographs at various temperatures under heating stage; from (a-f) successively. 

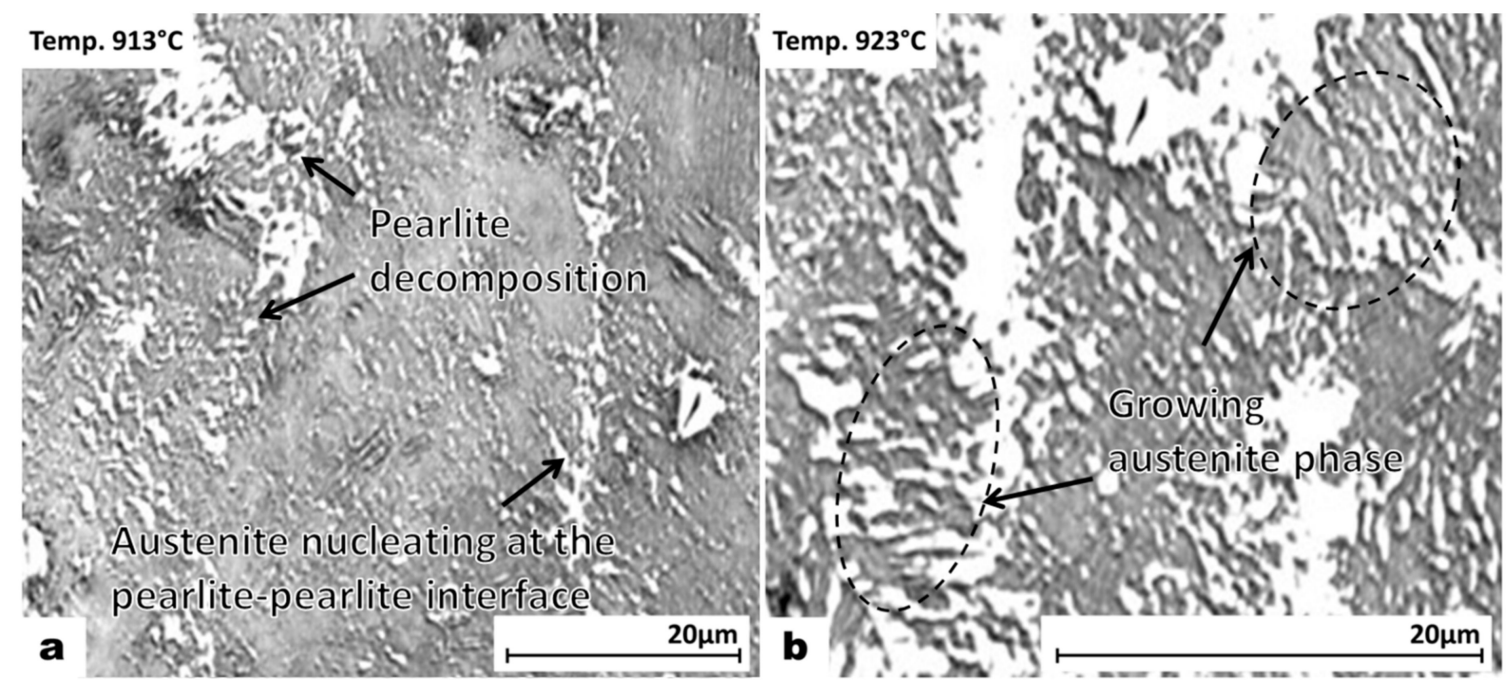

Figure 4. CSLM micrographs of nucleation sites and growth behavior of austenite. (a) Nucleation of austenite inside the pearlite colonies and at the pearlite-pearlite interface. (b) Growing mechanism of austenite by transforming pearlite.

\subsection{Microstructures at Different Cooling Rates}

Microstructures observed in CSLM, OM, and FESEM at different cooling rates are shown in Figure 5. At the highest cooling rate of $6{ }^{\circ} \mathrm{C} / \mathrm{s}$, the microstructure was mainly composed of martensite and bainite with little pearlite, as shown in Figure 5a. Since the austenite was inhomogeneous with fractions of untransformed ferrite, the fast cooling rate of $6{ }^{\circ} \mathrm{C} / \mathrm{s}$ did not provide enough time to carbon for long-range diffusion. Therefore, it is proposed that high concentration carbon was transformed into martensite and low carbon concentration austenite was transformed into bainite, whereas untransformed ferrite caused the formation of pearlite. Afterwards, lowering the cooling rate to $4{ }^{\circ} \mathrm{C} / \mathrm{s}$ homogenized the austenite, which caused the increase in pearlite growth. It has also been noticed that at a $4{ }^{\circ} \mathrm{C} / \mathrm{s}$ cooling rate, there are fractions of ferrite present in the microstructure, as shown in Figure $5 \mathrm{~b}$. Seo et al. argue that this kind of ferrite formation, shown in the FESEM micrograph of Figure 5b, is the reason for breakdown in the pearlite growth [27]. However, from 3 to $1{ }^{\circ} \mathrm{C} / \mathrm{s}$ cooling rates, the microstructure was complete pearlite along with pro-eutectoid ferrite at the grain boundaries. Figure $5 \mathrm{c}$ shows the complete pearlite microstructure at a $2{ }^{\circ} \mathrm{C} / \mathrm{s}$ cooling rate, where OM and FESEM micrographs show that there is pro-eutectoid ferrite at the grain boundaries. Microstructural observation reveals that $4{ }^{\circ} \mathrm{C} / \mathrm{s}$ is the maximum cooling rate where no martensite and no bainite form, and the microstructure is composed of pearlite. 


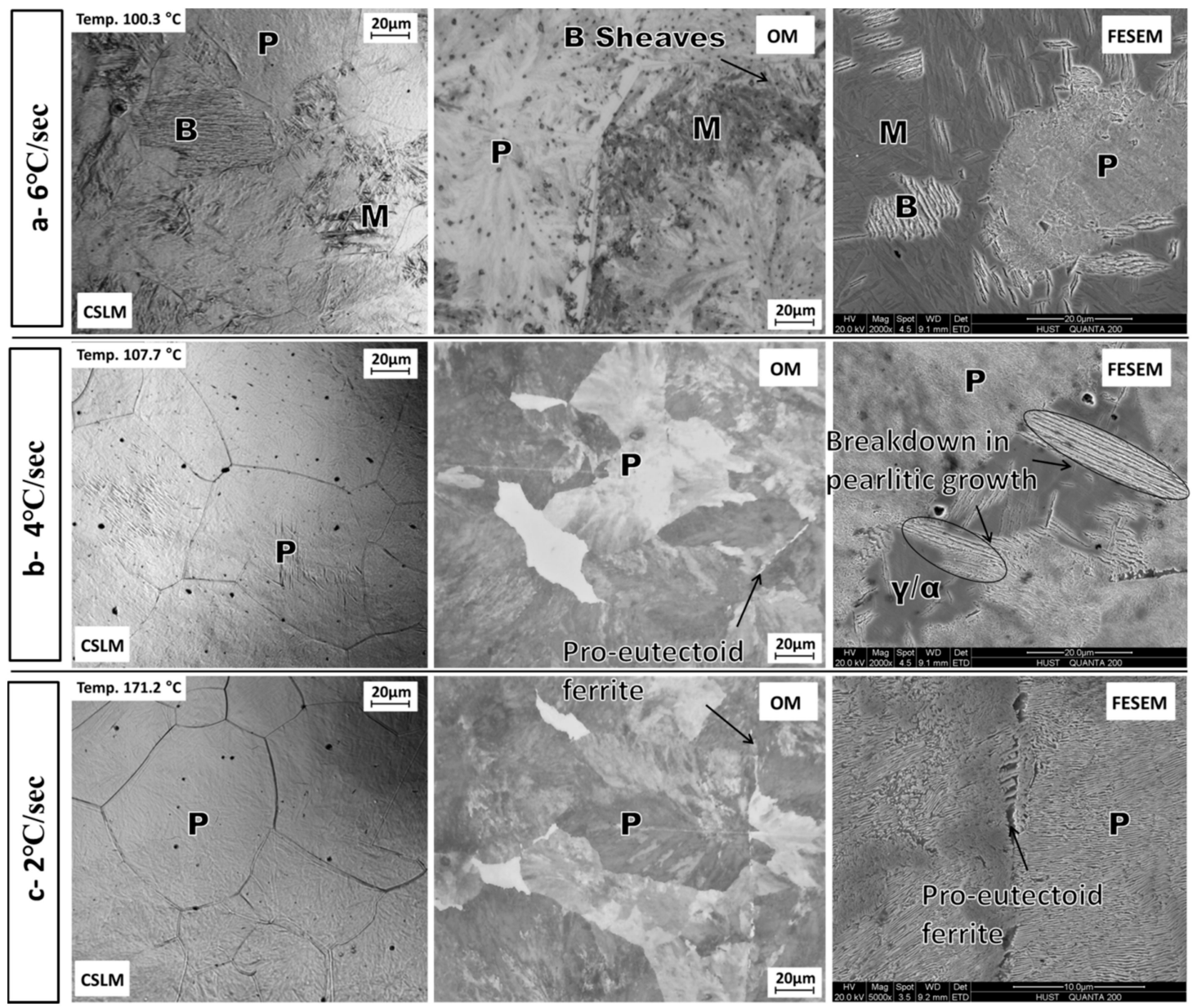

Figure 5. Microstructure obtained under different cooling rates. P: pearlite, B: Bainite, M: Martensite, $\gamma / \alpha$ : Austenite/Ferrite. (a) $6{ }^{\circ} \mathrm{C} / \mathrm{s} ;\left(\right.$ b) $4{ }^{\circ} \mathrm{C} / \mathrm{s}$; (c) $2{ }^{\circ} \mathrm{C} / \mathrm{s}$.

\subsubsection{Formation of Bainite and Martensite}

At $6{ }^{\circ} \mathrm{C} / \mathrm{s}$ there was martensite and bainite formation along with the pearlite, as shown in Figure 6 . The formation of bainite and martensite started at 513.2 and $307.9^{\circ} \mathrm{C}$, respectively. At a cooling rate of $6{ }^{\circ} \mathrm{C} / \mathrm{s}$, both the duration of pearlite transformation and the effective carbon displacement were lowest, which sustained the pearlite growth halfway. Afterwards, the newly grown plates of pro-eutectoid ferrite at the grain boundaries started the growth of bainite, as shown in Figure 6a. Bainite growth happened in the form of intra-granular sheaves, as shown in Figure $6 \mathrm{~b}, \mathrm{c}$. When the carbon diffusion was low enough to no longer support reconstructive transformation, the remaining austenite was transformed into martensite, as shown in Figure $6 \mathrm{~d}$. It has also been noticed that at a $6{ }^{\circ} \mathrm{C} / \mathrm{s}$ cooling rate, some fractions of martensite were also noticed within grains with intra-granular bainitic phase, as shown in Figure 6d. 


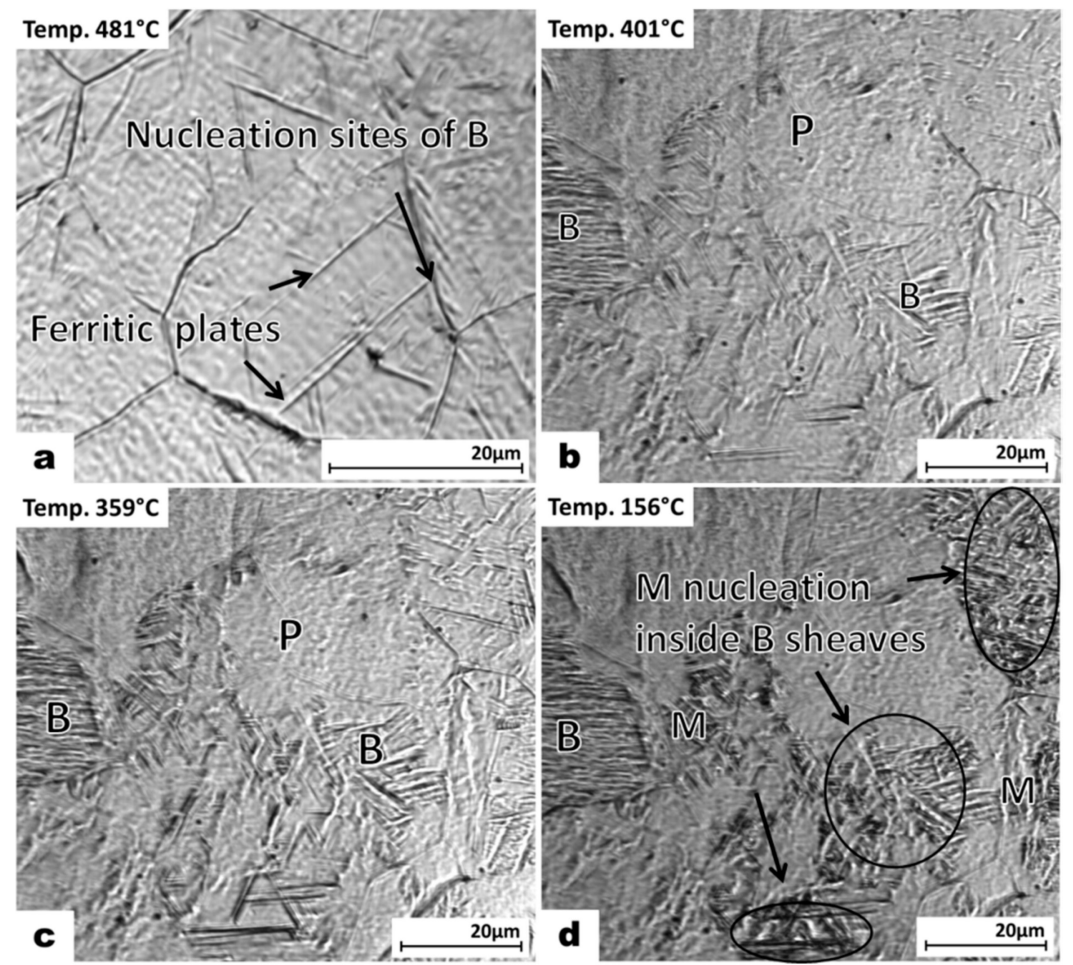

Figure 6. Formation of bainite and martensite at $6^{\circ} \mathrm{C} / \mathrm{s}$ cooling rate; From (a-d) successively. P: Pearlite, B: Bainite, M: Martensite.

\subsubsection{Pearlite Formation}

During cooling, the microstructure was composed of martensite, bainite, and little pearlite for $6{ }^{\circ} \mathrm{C} / \mathrm{s}$, whereas from 4 to $1{ }^{\circ} \mathrm{C} / \mathrm{s}$ the microstructure was complete pearlite. So, in the CGHAZ under different cooling rates, the austenite mainly decomposed into pearlite.

\section{Pearlite Nucleation}

Figure 7 shows the nucleation sites of pearlite formation at different cooling rates that are untransformed ferrite present in the grains and pro-eutectoid ferrite at the austenite grain boundaries. To make the behavior of nucleation sites clearer, the number nucleation sites at different cooling rates are shown in Figure 8, which were observed to be formed in the area of $200 \mu \mathrm{m} \times 190 \mu \mathrm{m}$ during the entire pearlite formation temperature range. Although the inclusion would have been the pearlite nucleation sites, the changing trend of pearlite number nucleation sites within the grains by lowering the cooling rate from 6 to $1{ }^{\circ} \mathrm{C} / \mathrm{s}$ reveals that the fractions of untransformed ferrite are the pearlite nucleation sites. Besides, at higher cooling rates, the high fractions of untransformed ferrite increased the number of pearlite nucleation sites. Contrastingly, Figure 9 clarifies that pro-eutectoid ferrite present at the grain boundaries is the nucleation site of pearlite formation. From Figure 8, at higher cooling rates untransformed ferrite is the potential nucleation site of pearlite formation, whereas at lower cooling rates pro-eutectoid ferrite at the austenite grain boundaries is the potential nucleation site of pearlite formation. 

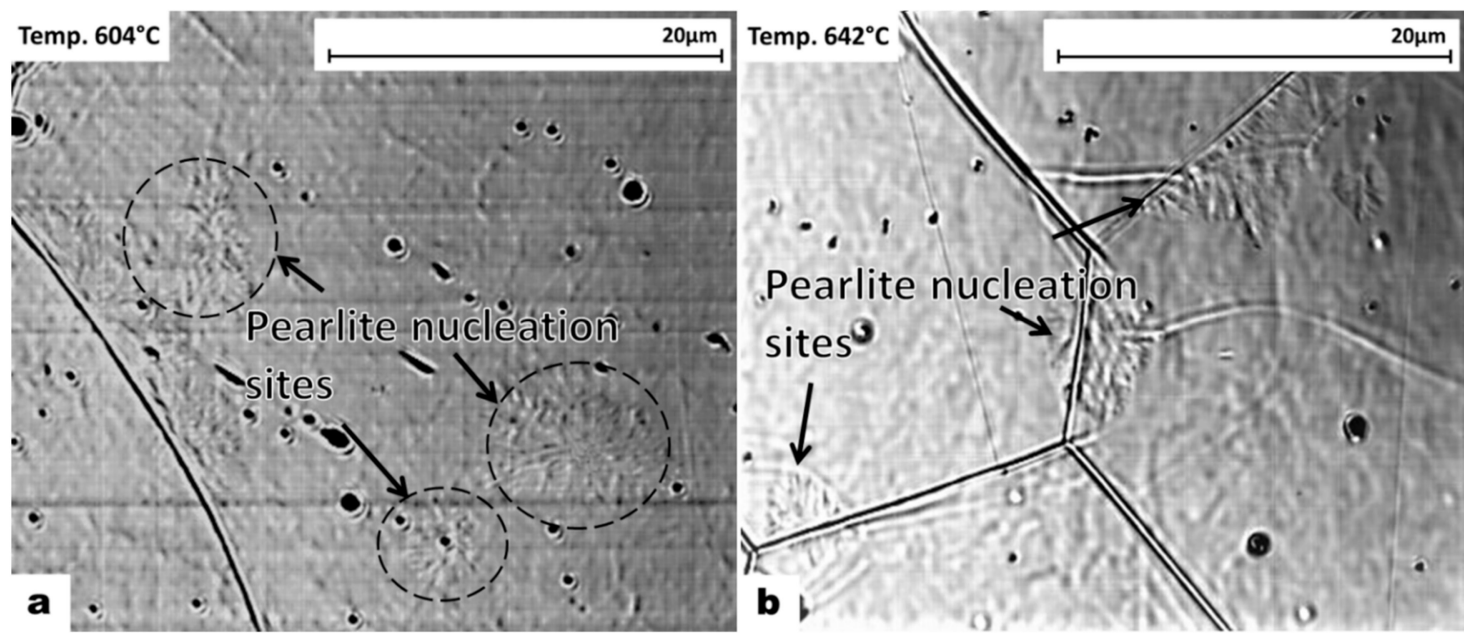

Figure 7. CSLM micrographs showing pearlite nucleation sites at different cooling rates. (a) $6{ }^{\circ} \mathrm{C} / \mathrm{s}$. (b) $1{ }^{\circ} \mathrm{C} / \mathrm{s}$.

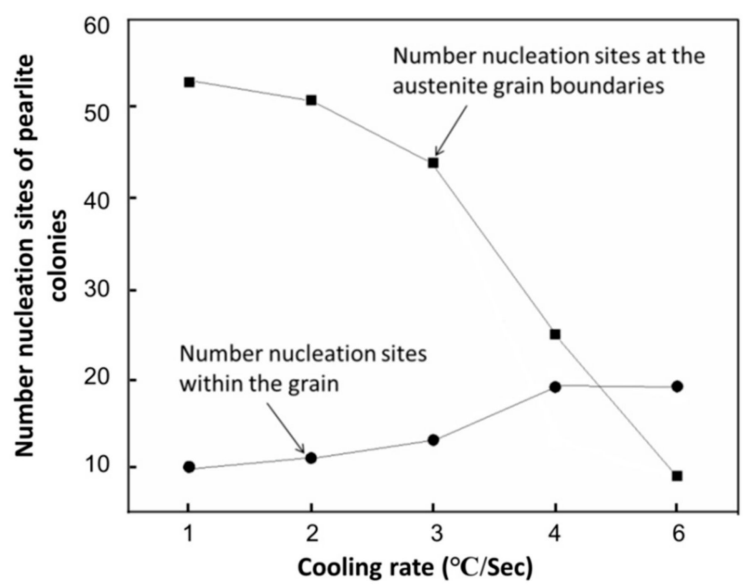

Figure 8. Number of nucleation sites of pearlite at different cooling rates in the area of $200 \mu \mathrm{m} \times 190 \mu \mathrm{m}$.

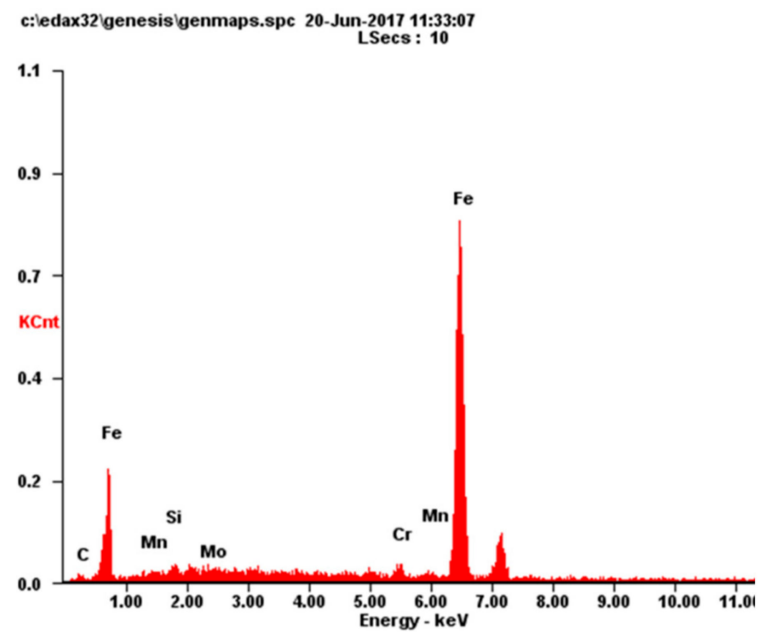

(a)

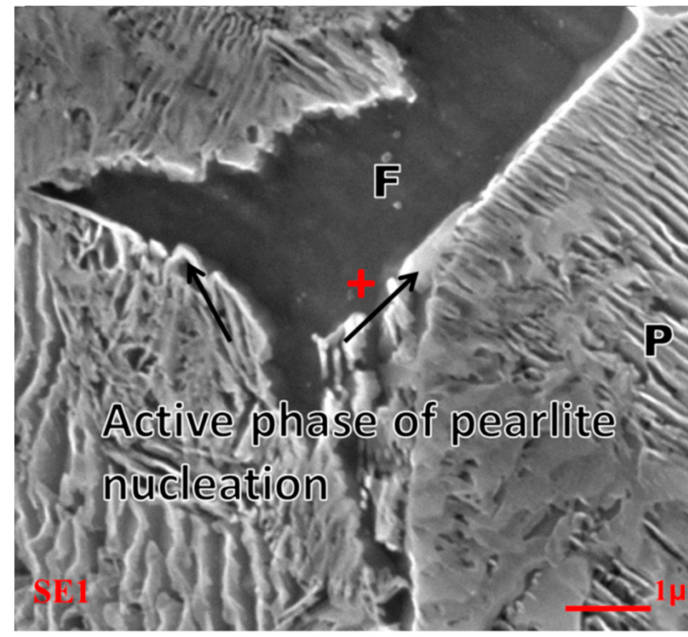

(b)

Figure 9. Pearlite nucleation site at the austenite grain boundary at $1{ }^{\circ} \mathrm{C} / \mathrm{s}$ cooling rate. P: Pearlite, F: Pro-eutectoid ferrite. (a) EDS spectrum of elemental quantitative data; (b) FESEM micrograph showing pro-eutectoid ferrite. 
Table 1 shows that changing the cooling rate from 6 to $1{ }^{\circ} \mathrm{C} / \mathrm{s}$ changed the pearlite start temperature from 603.9 to $651.5^{\circ} \mathrm{C}$, respectively. It can be noticed that at the highest cooling rate of $6{ }^{\circ} \mathrm{C} / \mathrm{s}$ where untransformed ferrite formed the potential nucleation sites, the pearlite start temperature is lowest at $603.9^{\circ} \mathrm{C}$. At a cooling rate of $4{ }^{\circ} \mathrm{C} / \mathrm{s}$ where the untransformed ferrite and the pro-eutectoid ferrite was equally the potential nucleation site of pearlite formation, the pearlite start temperature increased to $624.9^{\circ} \mathrm{C}$. Similarly, lowering the cooling rate, i.e., from 3 to $1{ }^{\circ} \mathrm{C} / \mathrm{s}$, increased the pearlite start temperature from 633.6 to $651.5^{\circ} \mathrm{C}$, respectively. It can be noticed that at lower pearlite start temperatures, the number of nucleation sites of pearlite is high, as shown in Figure 8. This higher number of pearlite nucleation sites at lower temperatures is due to the additional untransformed fractions of ferrite, which acted as the nucleation site. In contrast, by comparing the relationship between pearlite start temperature (Table 1) and the potential nucleation sites (Figure 8 ) at different cooling rates, it is proposed that the presence of untransformed ferrite lowers the pearlite start temperature by providing additional nucleation sites to pearlite. Furthermore, in the CGHAZ during electroslag welding thermal cycle, the cooling rate greatly affects the nucleation behavior of pearlite.

Table 1. Confocal scanning laser microcopy (CSLM)-based pearlite transformation characteristics at different cooling rates.

\begin{tabular}{cccccc}
\hline $\begin{array}{c}\text { Cooling } \\
\text { Rates, }{ }^{\circ} \mathbf{C} / \mathbf{s}\end{array}$ & $\begin{array}{c}\text { Pearlite Start } \\
\text { Temperature, } \\
{ }^{\circ} \mathbf{C}\end{array}$ & $\begin{array}{c}\text { Pearlite Finish } \\
\text { Temperature, } \\
{ }^{\circ} \mathbf{C}\end{array}$ & $\begin{array}{c}\text { Time of Pearlite } \\
\text { Transformation, } \\
{ }^{\circ} \mathbf{C}\end{array}$ & $\begin{array}{c}\text { Pearlite } \\
\text { Colony } \\
\text { Size, } \boldsymbol{\mu m}\end{array}$ & $\begin{array}{c}\text { Pearlite } \\
\text { Growth Rate, } \\
\mathbf{1 0}^{-5} \boldsymbol{\mu m}\end{array}$ \\
\hline 6 & 603.9 & 511.0 & 15.48 & - & - \\
\hline 3 & 624.9 & 538.0 & 21.72 & 43.16 & 0.91 \\
\hline 2 & 633.6 & 563.2 & 23.46 & 67.27 & 0.69 \\
\hline 1 & 642.2 & 589.1 & 26.55 & 68.88 & 0.37 \\
\hline
\end{tabular}

Pearlite Growth

Table 1 shows the temperature and duration of pearlite formation at different cooling rates. Furthermore, the pearlite colony size and the pearlite growth rate under different cooling rates where the entire transformation was pearlite, i.e., from 4 to $1{ }^{\circ} \mathrm{C} / \mathrm{s}$, were also measured and are shown in Table 1. The Zener-Hillert theory of pearlite transformation infers that the carbon diffusion rate and duration are the fundamental parameters that govern the entire pearlite formation $[28,29]$. In the present study, varying the cooling rate controlled the carbon diffusion and the duration. Conversely, the variation in pearlite start temperature and the pearlite growth rate are due to the different cooling rates. Based on the CSLM results, the growth rate of pearlite has been measured. Three values at each cooling rate were observed, whereas the average growth rate results are shown in Table 1 . The growth rate has been calculated by "distance covered by the complete pearlite colony growth divided by the time elapsed for the formation of the complete pearlite colony". Figure 10 shows the average pearlite growth by the time and temperature, which makes it clear to understand the growth rate calculation. It has been found that changing the cooling rate from 4 to $1^{\circ} \mathrm{C} / \mathrm{s}$ decreased the growth rate from $0.91 \mathrm{e}^{-5}$ to $0.29 \mathrm{e}^{-5} \mathrm{~m} / \mathrm{s}$, respectively. Based on the concept of Zener-Hillert theory, as mentioned earlier, carbon diffusion and the duration of pearlite formation can best describe the variation in pearlite growth rate $[28,29]$.

Bhadeshia has proposed a model which states the carbon diffusion co-efficient $(D)$ in austenite, as shown in Equation (1) [30].

$$
D=D^{\prime} \cdot \xi\{\theta\}
$$

Here, carbon diffusion co-efficient $(D)$ is the function of carbon concentration and temperature, whereas $D^{\prime}$ is the component of diffusivity independent of composition. $\xi\{\theta\}$ is the carbon factor, 
which depends on the coordination number of the octahedral sites in austenite lattice and carbon activity factor.

Seo et al. mentions that the component of diffusivity $D^{\prime}$, which provides insight into the carbon diffusion behavior at different pearlite transformation temperatures, is given in Equation (2) [27].

$$
D^{\prime}=\frac{\mathrm{k} P_{s}}{\mathrm{~h}} \exp \left(\frac{-\Delta \mathrm{G}}{\mathrm{k} P_{s}}\right)\left(\frac{\mathrm{d}_{\gamma}{ }^{2}}{3 \eta}\right)
$$

Here, $\mathrm{k}, \mathrm{h}$, and $\Delta \mathrm{G}$ are the Boltzmann constant, Planck constant, and the free energy of activation, respectively. Additionally, $\mathrm{d}_{\gamma}^{2}$ and $3 \eta$ are the distance between $\{002\}$ austenite plane and the activity co-efficient of the activated complex, respectively; which are the austenite phase components. The values of $\Delta \mathrm{G} / \mathrm{K}=21,230 \mathrm{~K}^{-1}$ and $\ln \left(3 \eta / d_{\gamma}^{2}\right)=31.84$ are found in the literature [30-32]. By Equation (2), the changing behavior of the component of diffusivity of carbon, at different cooling rates, was calculated and is shown in Figure 11a, which provides insight into the rate of carbon diffusion at different cooling rates. On the other side, the carbon diffusion co-efficient $(D)$, shown in Equation (1) can be used to evaluate the distance of carbon at different pearlite transformation temperatures. Equation (3) shows the maximum displacement covered by a single carbon atom in complete pearlite transformation duration at different cooling rates.

$$
<x^{2}>=q_{i} D\left(P_{f}-P_{s}\right)
$$

Here, $<x^{2}>$ is the mean square distance of diffused carbon. $q_{i}$ is the diffusion constant and depends on dimensions. For 2-dimentional displacement measurement, it will be equal to 4 . The carbon diffusion coefficients $(D)$ at different pearlite start temperatures (relative to cooling rates) are found by the Bhadeshia's work [30]. The carbon concentration is constant for a given rail steel and the pearlite start temperature varies slightly from 651.5 to $624.9^{\circ} \mathrm{C}$ by changing the cooling rate from 1 to $4{ }^{\circ} \mathrm{C} / \mathrm{s}$, respectively. Therefore, the carbon diffusion co-efficient is kept constant at $10^{-4} \mathrm{~m}^{2} / \mathrm{s}$. By using data from Table 1, the mean square distance of diffused carbon $\left\langle x^{2}>\right.$ is shown in Figure 11b.
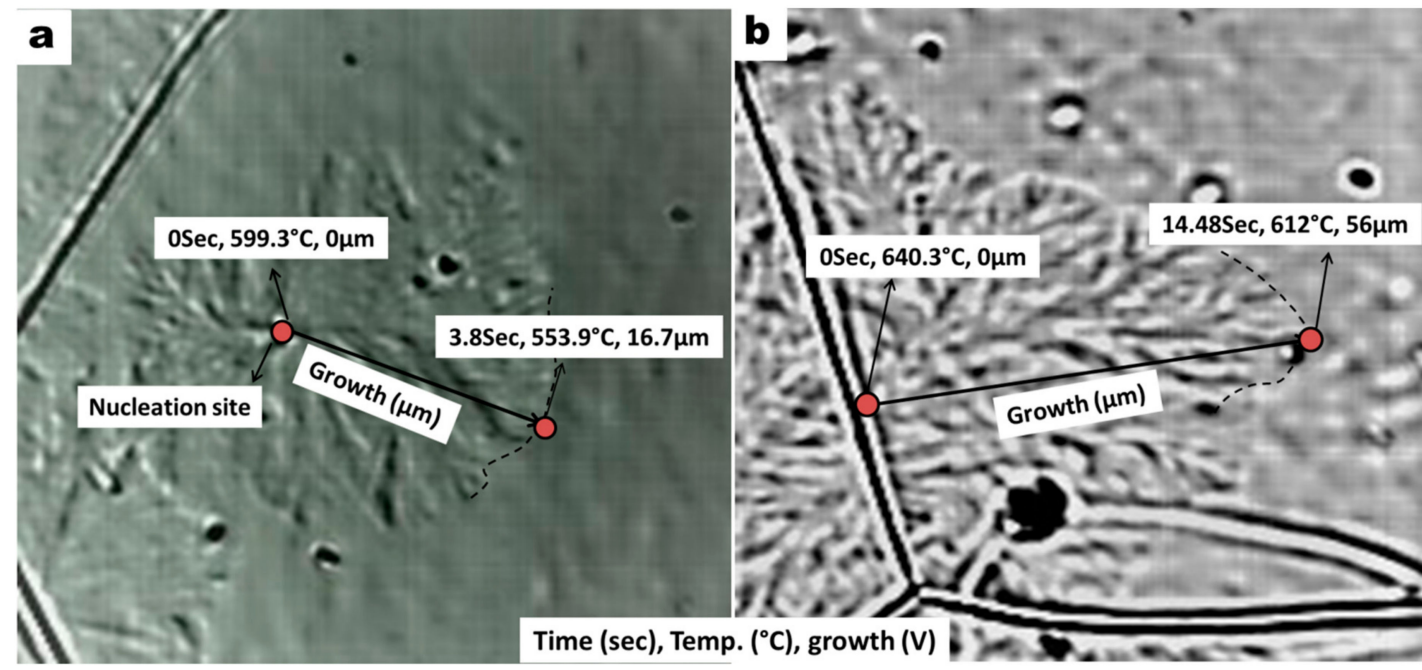

Figure 10. Pearlite growth at different times and temperatures. (a) $4{ }^{\circ} \mathrm{C} / \mathrm{s}$. (b) $1{ }^{\circ} \mathrm{C} / \mathrm{s}$.

From Figure 11, varying the cooling rate from 4 to $1{ }^{\circ} \mathrm{C} / \mathrm{s}$ increased the diffusion rate of carbon and the displacement of carbon. Besides, the duration of pearlite transformation increases by lowering the cooling rate from 4 to $1^{\circ} \mathrm{C} / \mathrm{s}$, successively, as shown in Table 1 . By combining all these factors, it has been proposed that at higher cooling rates of $4{ }^{\circ} \mathrm{C} / \mathrm{s}$, the duration of pearlite transformation was lowest. This lowest duration did not allow long-range displacement of carbon (Figure 11b), whereas the lowest diffusion rate (Figure 11a) made the pearlite growth localized. Therefore, the pearlite growth was highest $\left(0.91 \mathrm{e}^{-5} \mathrm{~m} / \mathrm{s}\right)$ at a $4{ }^{\circ} \mathrm{C} / \mathrm{s}$ cooling rate. When the cooling rates were lowered from 
3 to $1{ }^{\circ} \mathrm{C} / \mathrm{s}$, the duration of pearlite transformation increased, as shown in Table 1 . This increasing duration increased the mean value displacement of carbon atoms (Figure 11a), and the rate of carbon diffusion (Figure 11b). This is the reason why lowering the cooling rate from 3 to $1^{\circ} \mathrm{C} / \mathrm{s}$ reduced the pearlite growth rate from $0.69 \mathrm{e}^{-5}$ to $0.29 \mathrm{e}^{-5} \mathrm{~m} / \mathrm{s}$ respectively, although the pearlite volume fraction was increasing, which influenced the pearlite colony size.
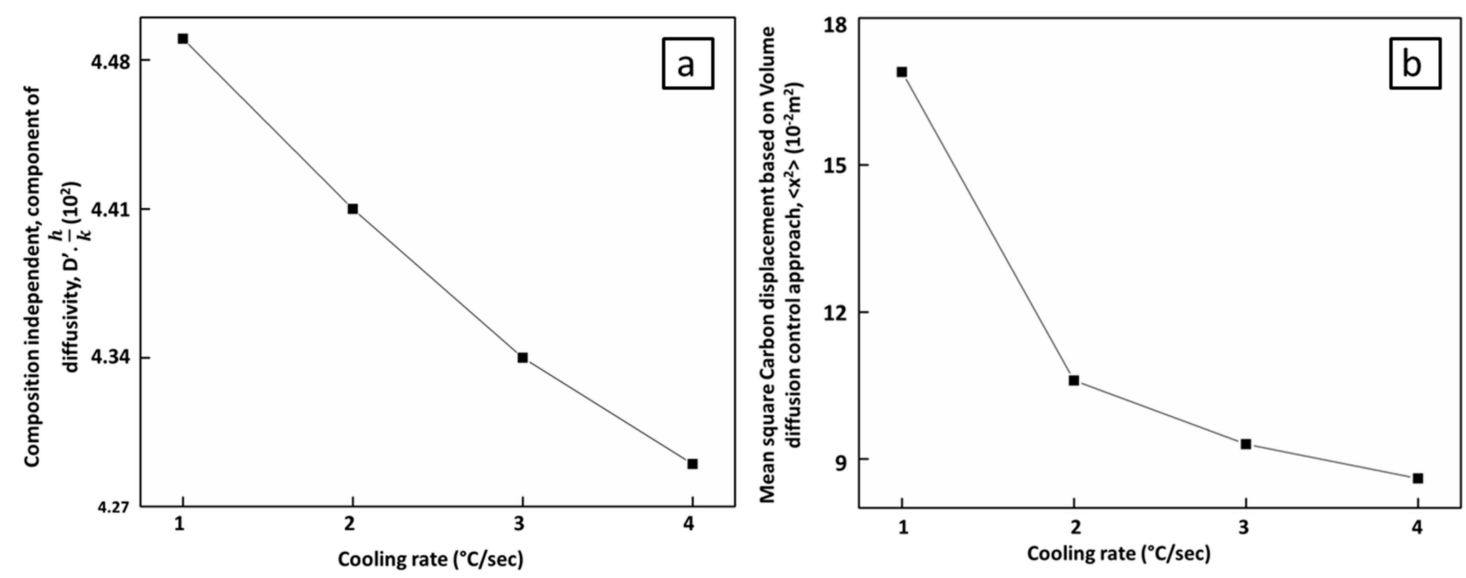

Figure 11. Based on volume-controlled diffusion of carbon. (a) Component of diffusivity of carbon at various cooling rates. (b) Mean square displacement of carbon at various cooling rates.

The influence of cooling rate on the pearlite colony size was also measured. From 4 to $1{ }^{\circ} \mathrm{C} / \mathrm{s}$ cooling rate the complete transformation zone was pearlite, whereas Figure 12 shows the FESEM micrographs of pearlite colony size variation at different cooling rates. Lowering the cooling rate from 4 to $1{ }^{\circ} \mathrm{C} / \mathrm{s}$ changed the pearlite colony size from 43.16 to $70.88 \mu \mathrm{m}$, respectively, as shown in Table 1 . From the results it can be seen that except for the $4{ }^{\circ} \mathrm{C} / \mathrm{s}$ cooling rate, the pearlite colony size was almost the same at all cooling rates, i.e., from 3 to $1^{\circ} \mathrm{C} / \mathrm{s}$. The small sized pearlite colonies at $4{ }^{\circ} \mathrm{C} / \mathrm{s}$ are due to the breakdown in pearlite growth. It is proposed that for the same heating rate and holding time during the welding thermal cycle, the formation of pearlite colony size will be the same under different cooling rates.

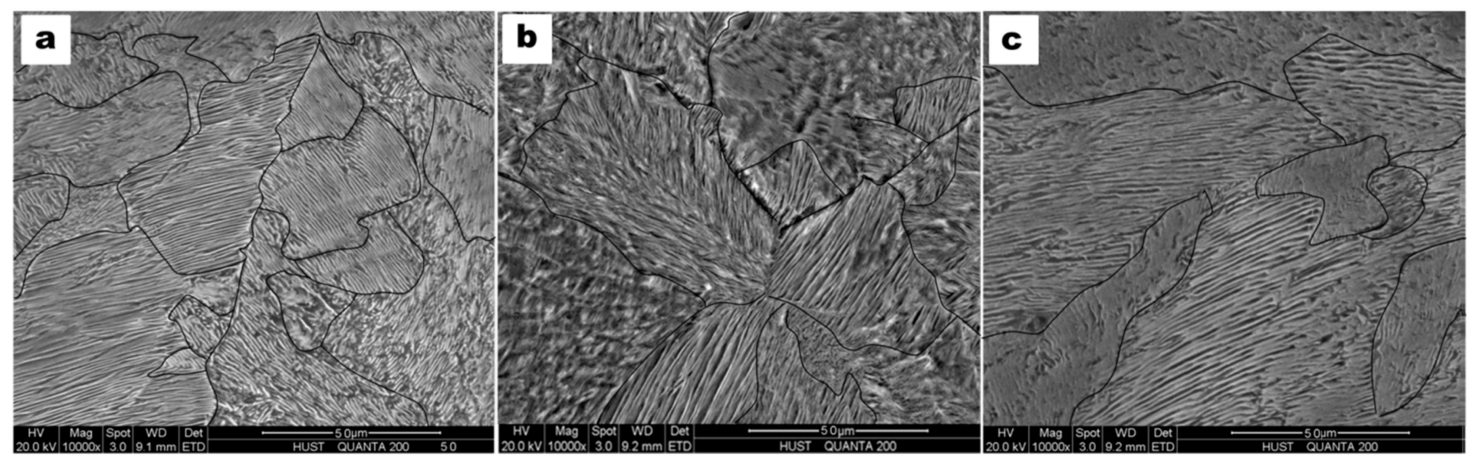

Figure 12. Pearlite colony size at different cooling rates. (a) $4{ }^{\circ} \mathrm{C} / \mathrm{s}$. (b) $3{ }^{\circ} \mathrm{C} / \mathrm{s}$. (c) $1{ }^{\circ} \mathrm{C} / \mathrm{s}$.

Above all, cooling rate is the actual parameter that governs duration of pearlite transformation, displacement of carbon, and the diffusion rate of carbon, which further affects the pearlite growth rate and pearlite colony size.

\section{Pearlite Interlamellar Spacing}

Pearlite interlamellar spacing of fully transformed pearlite microstructures, i.e., from 4 to $1{ }^{\circ} \mathrm{C} / \mathrm{s}$, was measured and the micrographs showing the variation of pearlite interlamellar spacing at different 
cooling rates are shown in Figure 13. Pearlite interlamellar spacing at $4{ }^{\circ} \mathrm{C} / \mathrm{s}$ was $117 \mathrm{~nm}, 163 \mathrm{~nm}$ at $3{ }^{\circ} \mathrm{C} / \mathrm{s}, 197 \mathrm{~nm}$ at $2{ }^{\circ} \mathrm{C} / \mathrm{s}$, and $253 \mathrm{~nm}$ at $1{ }^{\circ} \mathrm{C} / \mathrm{s}$. In the present study, varying cooling rates from 4 to $1{ }^{\circ} \mathrm{C} / \mathrm{s}$ reduced the pearlite start temperature. Meanwhile, different pearlite start temperatures at different cooling rates produced different pearlite growth rates, as shown in Table 1. Now, Nakajima et al. mention that a high pearlite growth rate will produce fine pearlite interlamellar spacing [33]. This is the reason that at a cooling rate of $4{ }^{\circ} \mathrm{C} / \mathrm{s}$, when the pearlite growth rate was highest, the pearlite interlamellar spacing is fine $(117 \mathrm{~nm})$. When the cooling rates were decreased to 3 and $2{ }^{\circ} \mathrm{C} / \mathrm{s}$, the slower pearlite growth rate increased the pearlite interlamellar spacing to 163 and $197 \mathrm{~nm}$, respectively. Finally, at the lowest cooling rate of $1{ }^{\circ} \mathrm{C} / \mathrm{s}$, the lowest pearlite growth rate produced a coarser pearlite interlamellar spacing of $253 \mathrm{~nm}$. It is concluded that cooling rate is the main factor that governs the pearlite interlamellar spacing.
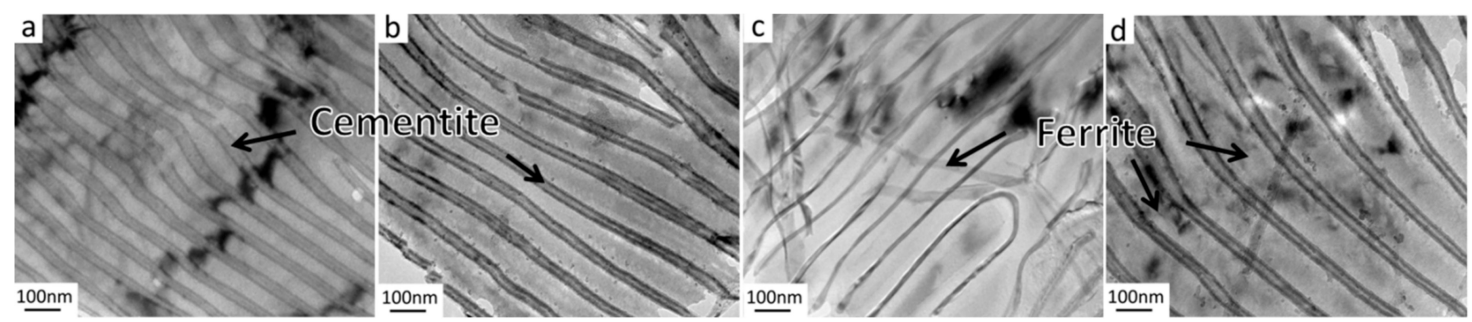

Figure 13. Pearlite interlamellar spacing at different cooling rates. (a) $4{ }^{\circ} \mathrm{C} / \mathrm{s}$. (b) $3{ }^{\circ} \mathrm{C} / \mathrm{s}$. (c) $2{ }^{\circ} \mathrm{C} / \mathrm{s}$. (d) $1{ }^{\circ} \mathrm{C} / \mathrm{s}$.

Based on the above experimental results, the behavior of phase transformation at different cooling rates can be well summarized by a continuous cooling transformation diagram, as CCT is calculated based on CSLM experimental results and is shown in Figure 14, where the cooling rate has a substantial effect on the microstructure transformation.

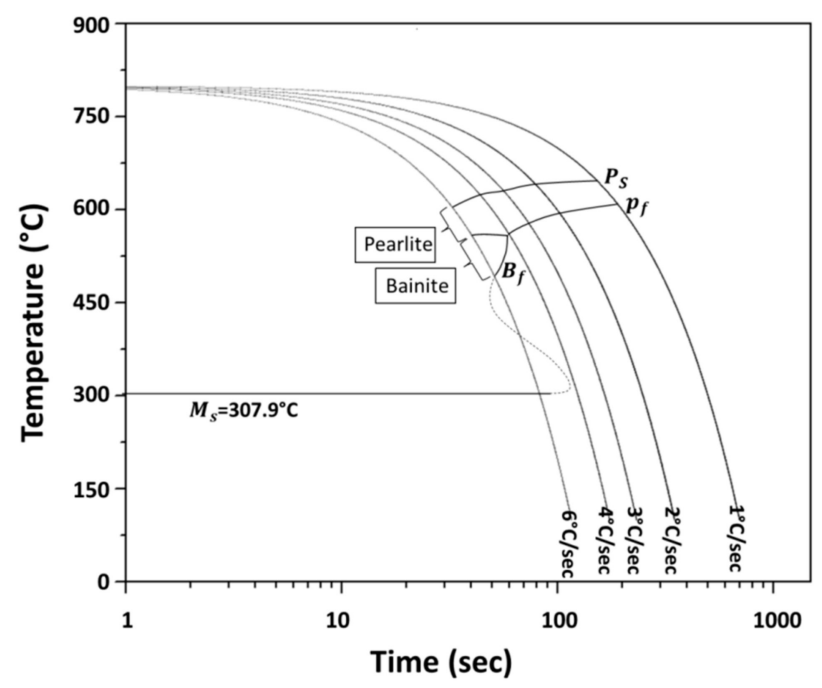

Figure 14. Measured continuous cooling transformation (CCT) diagram based on CSLM results.

\subsection{Mechanical Properties}

Table 2 shows the mechanical properties of the CGHAZ at different cooling rates ranging from 6 to $1{ }^{\circ} \mathrm{C} / \mathrm{s}$. From the results, lowering the cooling rate from 6 to $1{ }^{\circ} \mathrm{C} / \mathrm{s}$ reduced the hardness from 602 to $342 \mathrm{HV}$, tensile strength from and 1392 to $1189 \mathrm{MPa}$, and increased the toughness from 4.5 to $8.2 \mathrm{~J}$, respectively. 
Table 2. Mechanical properties at different cooling rates.

\begin{tabular}{cccc}
\hline Cooling Rate, ${ }^{\circ} \mathbf{C} / \mathbf{s}$ & $\begin{array}{c}\text { Hardness, HV } \\
\text { (Standard Deviation) }\end{array}$ & $\begin{array}{c}\text { Tensile Strength, MPa } \\
\text { (Standard Deviation) }\end{array}$ & $\begin{array}{c}\text { Toughness, J } \\
\text { (Standard Deviation) }\end{array}$ \\
\hline 6 & $602(1.01)$ & $1392(2.54)$ & $4.5(0.05)$ \\
\hline 4 & $425(1.84)$ & $1077(3.83)$ & $9.1(0.05)$ \\
\hline 3 & $392(1.81)$ & $1299(2.74)$ & $8.2(0.27)$ \\
\hline 2 & $370(1.24)$ & $1290(3.74)$ & $8.1(0.08)$ \\
\hline 1 & $354(0.89)$ & $1189(2.24)$ & $8.2(0.08)$ \\
\hline
\end{tabular}

\subsubsection{Hardness}

The hardness at different cooling rates are shown in Table 2. At a higher cooling rate of $6{ }^{\circ} \mathrm{C} / \mathrm{s}$ hardness is highest of $602 \mathrm{HV}$, which can be associated with the vast volume fraction of martensite and bainite, as shown in Figure 5a. Wang et. al. believes that hardness in a pearlite microstructure happens to be directly influenced by the pearlite interlamellar spacing, as fine pearlite interlamellar spacing will produce higher hardness [34]. Therefore, from 4 to $1{ }^{\circ} \mathrm{C} / \mathrm{s}$ where microstructure was completely pearlite, the pearlite interlamellar spacing affected the hardness. At cooling rate of $4{ }^{\circ} \mathrm{C} / \mathrm{s}$, the microstructure was composed of pearlite with fine interlamellar spacing of $117 \mathrm{~nm}$, which produced a high hardness of $425 \mathrm{HV}$, as shown in Table 2. Afterwards, for the cooling rates of 3 and $2{ }^{\circ} \mathrm{C} / \mathrm{s}$, increasing interlamellar pearlite spacing from 163 to $197 \mathrm{~nm}$ lowered the hardness from 392 to $370 \mathrm{HV}$, respectively. However, at the lowest cooling rate of $1^{\circ} \mathrm{C} / \mathrm{s}$, hardness was lowest at $354 \mathrm{HV}$, which was because of the coarse pearlite interlamellar spacing of $253 \mathrm{~nm}$. For the cooling rates where the entire transformation was pearlitic, i.e., from 4 to $1{ }^{\circ} \mathrm{C} / \mathrm{s}$, the decreasing pearlite interlamellar spacing increased the cementite content that can be seen in Figure 13. This is the reason why hardness was found to be increasing by decreasing the pearlite interlamellar spacing.

\subsubsection{Tensile Strength}

Tensile strength in the CGHAZ at different cooling rates is shown in Table 2. At $6{ }^{\circ} \mathrm{C} / \mathrm{s}$, tensile strength is highest at $1392 \mathrm{MPa}$, which is due to the minimal pearlite along with excessive martensite and bainite. From 4 to $1{ }^{\circ} \mathrm{C} / \mathrm{s}$, the microstructure was completely composed of pearlite, the tensile strengths for 4, 3, 2, and $1{ }^{\circ} \mathrm{C} / \mathrm{s}$ were 1077, 1299, 1290, and $1189 \mathrm{MPa}$, respectively, as shown in Table 2 . It is well known that in a fully pearlitic microstructure, pearlite interlamellar spacing governs the tensile strength. However, it is observed that at a very fine pearlite interlamellar spacing of $117 \mathrm{~nm}$ (achieved at $4{ }^{\circ} \mathrm{C} / \mathrm{s}$ cooling rate) the tensile strength is lowest (1077 MPa). This lowest tensile strength is because of the sporadic ferrite phase present in the microstructure, as shown in Figure $5 b$, as during tensile testing cracks probably first formed in the soft ferrite phase. Afterwards, when the microstructure was complete pearlite (at 3,2 , and $1{ }^{\circ} \mathrm{C} / \mathrm{s}$ ) the pearlite interlamellar spacing of 163,197 , and $253 \mathrm{~nm}$, respectively, produced tensile strengths of 1299,1290 , and $1089 \mathrm{MPa}$, respectively.

\subsubsection{Toughness}

Toughness in the CGHAZ against different cooling rates is shown in Table 2. Martensite is a brittle microstructure which has produced the lowest toughness of $4.5 \mathrm{~J}$ at the highest cooling rate of $6{ }^{\circ} \mathrm{C} / \mathrm{s}$. The FESEM fractograph shown in Figure 15a shows the brittle fracture of the CGHAZ at a $6{ }^{\circ} \mathrm{C} / \mathrm{s}$ cooling rate. On the other side, for the cooling rates from 4 to $1{ }^{\circ} \mathrm{C} / \mathrm{s}$, where the entire transformation was pearlite, the toughness is highest at $4{ }^{\circ} \mathrm{C} / \mathrm{s}$ but it is almost same for the cooling rates of 3, 2, and $1{ }^{\circ} \mathrm{C} / \mathrm{s}$, as shown in Table 2. In the FESEM fractographs shown in Figure $15 \mathrm{~b}-\mathrm{d}$, the pearlite colonies show cleavage facets that can be associated with the brittle fracture. This implies that the pearlite microstructure is a bicrystal of cementite and ferrite, rather than the interlamellar spacing which defines the length scale of fracture. When the crack propagated from one pearlite colony to 
other pearlite colony, however, there was hindrance of crack propagation that can be observed by noticing the boundaries of pearlite colonies in the fractographs of Figure $15 \mathrm{~b}-\mathrm{d}$. It reveals that pearlite colony size is the fundamental parameter that affects the toughness. This is the reason why at a $4{ }^{\circ} \mathrm{C} / \mathrm{s}$ cooling rate when the pearlite colony size was small $(43.16 \mu \mathrm{m})$, as shown in Table 1 , the toughness was highest $(9.1 \mathrm{~J})$. However, cooling rates from 3 to $1{ }^{\circ} \mathrm{C} / \mathrm{s}$, where pearlite colonies were nearly the same size from 67.27 to $70.61 \mu \mathrm{m}$, respectively, produced almost same toughness of $8.2 \mathrm{~J}$. It has been evaluated that pearlite colony size governs the toughness of the CGHAZ, rather than the pearlite interlamellar spacing.

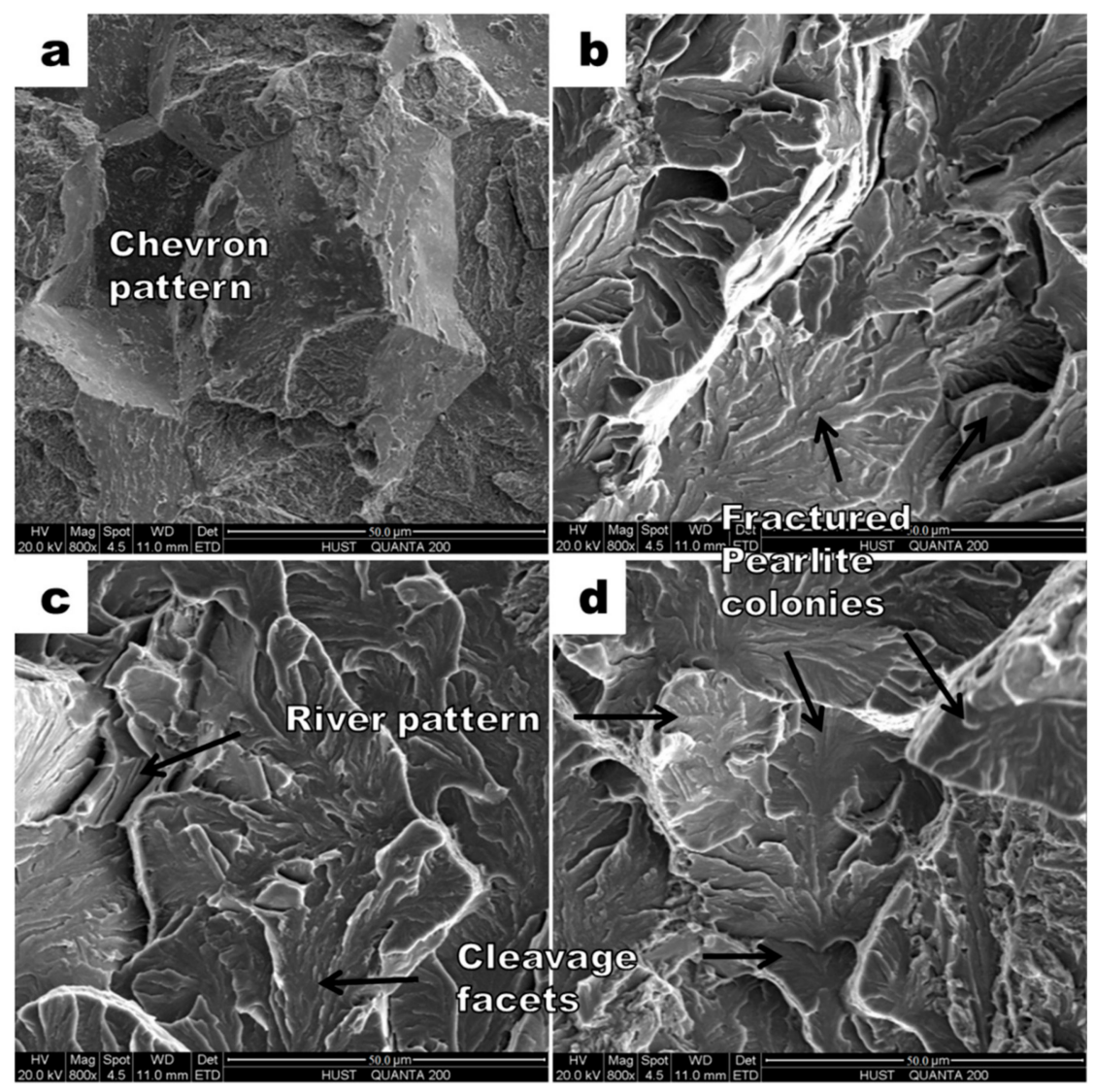

Figure 15. Field emission scanning electron microscope (FESEM) fractographs at different cooling rates. (a) $6{ }^{\circ} \mathrm{C} / \mathrm{s}$. (b) $4{ }^{\circ} \mathrm{C} / \mathrm{s}$. (c) $2{ }^{\circ} \mathrm{C} / \mathrm{s}$. (d) $1{ }^{\circ} \mathrm{C} / \mathrm{s}$.

\section{Conclusions}

Experimental analysis of the effect of cooling rate, ranging from 6 to $1{ }^{\circ} \mathrm{C} / \mathrm{s}$, on microstructure and mechanical properties in the thermally simulated CGHAZ of electroslag welded pearlitic rail steel using a confocal scanning laser microscope (CSLM) and Gleeble 3500 thermo-mechanical simulator has been investigated. The following are the salient conclusions:

1. High heating rate, in the CGHAZ of pearlitic rail steel, produced inhomogeneous austenite with fractions of untransformed ferrite, which lowered the pearlite start temperature by providing additional nucleation sites for pearlite formation.

2. Higher cooling rate of $6^{\circ} \mathrm{C} / \mathrm{s}$ in the CGHAZ led to the formation of martensite and bainite with minimal pearlite, whereas lowering the cooling rate from 4 to $1^{\circ} \mathrm{C} / \mathrm{s}$ produced complete pearlite formation.

3. At a cooling rates of $6{ }^{\circ} \mathrm{C} / \mathrm{s}$, untransformed ferrite formed the potential nucleation sites of pearlite formation, whereas at cooling rates from 4 to $1^{\circ} \mathrm{C} / \mathrm{s}$, pro-eutectoid ferrite at the austenite grain boundaries formed the potential nucleation sites of pearlite formation. 
4. Lowering the cooling rate from 4 to $1^{\circ} \mathrm{C} / \mathrm{s}$ in the CGHAZ increased the pearlite start temperature and decreased the pearlite growth rate. Meanwhile, increasing the pearlite start temperature enlarged the pearlite interlamellar spacing.

5. In the CGHAZ of pearlitic rail steel, narrow pearlite interlamellar spacing produced high hardness and high tensile strength. Additionally, toughness was found to be greatly controlled by pearlite colony size rather than the pearlite interlamellar spacing, where small pearlite colony size produced higher toughness.

6. A cooling rate of $4{ }^{\circ} \mathrm{C} / \mathrm{s}$ led to the formation of pearlite with fine interlamellar spacing of $117 \mathrm{~nm}$ in the CGHAZ of electroslag welded pearlitic rail steel where the hardness is $425 \mathrm{HV}$, tensile strength is $1077 \mathrm{MPa}$, and toughness is $9.1 \mathrm{~J}$.

Author Contributions: Conceptualization, S.Y. and A.R.K.; methodology, A.R.K and H.W.; validation, A.R.K. and S.Y.; formal analysis, A.R.K., Y.J. and H.W.; investigation, A.R.K., Y.J. and H.W.; resources, A.R.K. and H.W.; data curation, A.R.K. and S.Y.; writing—original draft preparation, A.R.K. and H.W.; writing—review and editing, A.R.K. and S.Y.; visualization, A.R.K. and S.Y.; supervision, A.R.K. and S.Y.; project administration, S.Y., A.R.K. and Y.J.

Funding: This research received no external funding.

Acknowledgments: The authors want to thank the technical support from the Analytical and Testing Center in Huazhong University of Science and Technology, Wuhan.

Conflicts of Interest: The authors declare no conflict of interest.

\section{References}

1. Porcaro, R.R.; Faria, G.L.; Godefroid, L.B.; Apolonio, G.R.; Cândido, L.C.; Pinto, E.S. Microstructure and mechanical properties of a flash butt welded pearlitic rail. J. Mater. Process. Technol. 2019, 270, $20-27$. [CrossRef]

2. Correa, N.; Vadillo, G.E.; Santamaria, J.; Gomez, J. On the study of train-track dynamic interactions caused by rail welds on discrete supported rails. Wear 2014, 314, 291-298. [CrossRef]

3. Romano, S.; Beretta, S.; Galli, G.S.; Riccardo, R. Determination of inspection intervals for welded rails joints on a regional network. Procedia Struct. Integr. 2017, 4, 87-94. [CrossRef]

4. Steenbergen, M.J.M.M.; Van-Bezooijen, R.W. Rail Welds, Wheel-Rail Interface Handbook; WoodHead Publishing: Sawston, UK, 2014; pp. 377-408.

5. Sanudo, R.; Olio, L.D.; Casado, J.A.; Carrascal, I.A.; Diego, S. Track transitions in railways, A review. Constr. Build. Mater. 2016, 112, 140-157. [CrossRef]

6. Jun, H.K.; Seo, J.W.; Jeon, I.S.; Lee, S.H.; Chang, Y.S. Fracture and fatigue crack growth analyses on a weld-repaired railway rail. Eng. Fail. Anal. 2016, 59, 478-492. [CrossRef]

7. Danks, D.; Turpin, B. Recent advances in field electroslag welding. In Proceedings of the 2005 Annual Conference, AREMA, Omaha, NE, USA, 24 May 2005.

8. Leonhard, W.; Bagher, N.M.; Norbert, E. Numerical simulation of pearlite formation during welding of rails. In Proceedings of the 10th International Conference on Trends in Welding, Tokyo, Japan, 11-14 October 2016.

9. Micenko, P.; Li, H. Double Dip Hardness Profiles in Rail Weld Heat Affected Zone-Literature and Research Review Report. CRC for Rail Innovation: Brisbane, Australia, 2016.

10. Grigorenko, G.; Kostin, V.; Zhukov, V.; Zuber, T. Peculiarities of structural transformations in HAZ metal of rail steel M76 joint produced by flash-butt welding. J. Phys. Sci. Appl. 2016, 5, 54-65. [CrossRef]

11. Poznyakov, V.D.; Kiriakov, V.M.; Gajvoronsky, A.A.; Klapatyuk, A.V.; Shishkevich, O.S. Properties of welded joints of rail steel in electric arc welding. Paton Weld. J. 2010, 8, 16-20.

12. Wu, K.M.; Bhadeshia, H.K.D.H. Extremely fine pearlite by continuous cooling transformation. Scr. Mater. 2012, 67, 53-56. [CrossRef]

13. Sahay, S.S.; Mohapatra, G.; Totten, G.E. Overview of pearlitic rail steel: Accelerated cooling, quenching, microstructure, and mechanical properties. J. ASTM 2009, 6, 1-26.

14. Modi, O.P.; Deshmukh, N.; Mondal, D.P.; Jha, A.K.; Yegneswaran, A.H.; Khaira, H.K. Effect of interlamellar spacing on the mechanical properties of $0.65 \%$ C steel. Mater. Charact. 2001, 46, 347-352. [CrossRef] 
15. Li, Z.; Wen, Z.; Su, F.; Zhang, R.; Zhou, Z. Modelling research on pearlite-to-austenite transformation in hypereutectoid steel containing Cr. J. Alloys Compd. 2017, 727, 1050-1056. [CrossRef]

16. Yang, Z.G.; Xia, Y.; Zhang, C. Calculation of austenitization rate of lamellar pearlite. Acta Metall. Sin. 2013, 47, 890-896. [CrossRef]

17. Palmer, T.Y.A.; Elmer, J.W. Direct observation of the $\alpha-\gamma$ transformation at different input powers in the heat affected zone of 1045 C-Mn steel arc welds observed by spatially resolved X-ray diffraction. Metall. Mater. Trans. A 2005, 36, 3353-3369. [CrossRef]

18. Elmer, J.W.; Palmer, T.A.; Zhang, W.; Wood, B.; DebRoy, T. Kinetics of phase transformations occurring in the HAZ of C-Mn steel welds based on direct observations. Acta Mater. 2003, 51, 3333-3349. [CrossRef]

19. ASTM International. Standard Test Methods for Preparation of Metallographic Materials; ASTM E003-11; ASTM International: West Conshohocken, PA, USA, 2017.

20. Caballero, F.G.; de Andres, C.G.; Capdevila, C. Characterization and morphological analysis of pearlite in a eutectoid steel. Mater. Charact. 2000, 45, 111-116. [CrossRef]

21. Caballero, F.G.; de Andres, C.G.; Capdevila, C. Modeling of the interlamellar spacing of isothermally formed pearlite in a eutectoid steel. Scr. Mater. 2000, 42, 537-542. [CrossRef]

22. ASTM International. Standard Test Methods for Vickers Hardness and Knoop Hardness of Metallic Materials; ASTM E092-17; ASTM International: West Conshohocken, PA, USA, 2017.

23. ASTM International. Standard Test Methods and Definitions for Mechanical Testing of Steel Products; ASTM A370-03a; ASTM International: West Conshohocken, PA, USA, 2003.

24. ASTM International. Standard Test Method for Notched Bar Impact Testing of Metallic Materials; ASTM E23-02a; ASTM International: West Conshohocken, PA, USA, 2002.

25. Jacot, A.; Rappaz, M.; Reed, R.C. Modeling of austenitization from the pearlite structure in steel. Acta Mater. 1998, 46, 3949-3962. [CrossRef]

26. Atkinson, C.; Akbay, T.; Reed, R.C. Theory for austenitization from ferrite/cementite mictrures in Fe-C-X steels. Acta Mater. 1995, 43, 2013-2031. [CrossRef]

27. Seo, S.W.; Bhadeshia, H.K.D.H. Pearlite growth rate in Fe-C and Fe-Mn-C steels. Mater. Sci. Technol. 2015, 31, 487-493. [CrossRef]

28. Zener, C. Kinetics of the decomposition of austenite. Trans. AIME 1945, 167, 550-595.

29. Hillert, M. Phase Equilibria, Phase Diagrams and Phase Transformations, 2nd ed.; Cambridge University Press: Cambridge, UK, 2012; pp. 155-184.

30. Bhadeshia, H.K.D.H. Diffusion of carbon in austenite. Met. Sci. 1998, 15, 477-480. [CrossRef]

31. Pandit, A.S.; Bhadeshia, H.K.D.H. Mixed diffusion-controlled growth of pearlite in binary steel. Proc. R. Soc. A 2010, 467, 508-521. [CrossRef]

32. Marder, A.R.; Mramfitt, B.L. Effect of continuous cooling on the morphology and kinetics of perlite. Metall. Mater. Trans. A 1975, 6, 2009-2014. [CrossRef]

33. Nakajima, K.; Apel, M.; Steinbach, I. The role of diffusion in ferrite on the kinetics of cooperative growth of pearlite: A multiphase field study. Acta Mater. 2006, 54, 3665-3672. [CrossRef]

34. Wang, M.; Zhang, F.; Yang, Z. Effects of high-temperature deformation and cooling process on the microstructure and mechanical properties of an ultra-strength pearlite steel. Mater. Des. 2017, 114, 102-110. [CrossRef]

(C) 2019 by the authors. Licensee MDPI, Basel, Switzerland. This article is an open access article distributed under the terms and conditions of the Creative Commons Attribution (CC BY) license (http://creativecommons.org/licenses/by/4.0/). 